\title{
The current state of the German island dialects in the Lower Volga region
}

\author{
Natalia A. Frolova ${ }^{1, *}$, IrenaV. Aleshchanova ${ }^{1}$, and Marina R. Zheltukhina ${ }^{2}$ \\ ${ }^{1}$ KTI(branch) of VST, Foreign Languages and Humanities Department, 6A Lenin Street, 403874, Kamyshin, Russia \\ ${ }^{2}$ Volgograd State Socio-Pedagogical University, English Philology Department, 27, Lenin Av., 400066, Volgograd, Russia
}

\begin{abstract}
This study is devoted to the fate of the German language island dialects in foreign language environment. The authors has explored the nature of the changes, the degree of dialectal features loss, indicate the possibility of developing new features. The sub dialects as elements of the language system were found to continue existing even outside the native language range. The peculiarities of language systems existence in extreme conflict conditions like those of the German dialects on the Volga region territory are of particular research interest, as they are influenced not only by the native language system, but also by another foreign language and culture. Language relations are determined not simply by coexistence of the two language systems, the German and Russian ones, and bilingualism of the majority of the German ethnic group representatives, but by the complex specificity of language processes in the past and even more complicated, specific current language situation, which determined the relevance of the article theme. $n$.
\end{abstract}

\section{Introduction}

Those languages which function away from the residential territory of the majority of their speakers are indicated as separate islands on the linguistic map of Russia. These islands include a number of German settlements. The Volga Germans had to live in special conditions of foreign language environment. They experienced complex ethnic processes that had an impact on the peculiarities of the German sub dialects present state.

About 384,138 (three hundred eighty four thousand one hundred and thirty eight) ethnic Germans now live in Russia [1]. Their ancestors migrated from Germany to Russia in the middle of the 18th century. Having lost their direct relaishionship with the main group of native speakers and their original language, the Germans formed a new language community with its unique substructure on the Russian territory in the areas of their dense residence. The results of the German language and culture contacts with the Russian linguo-cultural community took many forms at different levels of German settlers' national and cultural consciousness and their language system. These depended on the degree of borrowed elements entry into the native language system. Differences are observed in the frequency of new elements use, in the degree and nature of their assimilation [2].

Interest of linguists in the problem of interaction of languages in different conditions of their existence and development has been growing in Russia since the middle of the last century. Special attention was paid to the problem of bilingualism in conditions of national and cultural isolation, characterized by multidirectional tendencies of their development. In particular, these are tendencies to preserve archaic features and assimilate various innovations associated both with changing their language systems, and foreign language environment influence [3].

The choice of the research topic was influenced by the fact that no consensus exists on the fate of island dialects, the ongoing changes nature, and the degree of dialect features loss, the possibility of new features development in the domestic and foreign linguistics. The current processes complexity moves the problem of island dialects beyond the national linguistics towards general linguistics and social linguistics.

Contemporary realities lead us to the need to address the problem of island dialects preservation as part of the modern paradigm of man and society. In this case national and cultural identity is considered as a unity of stability and variability, giving an individual the possibility of self-expression, changing and modifying with an individual over time, creating the prospect of combining with continuity.

The national identity manifestation in foreign environment in extreme conditions of survival differs from living conditions of political, economic and religious stability in a state. Individual consciousness is in constant motion towards a more prestigious culture and language, or at least towards equal ones. It never moves in the opposite direction. When two cultures and two languages come into contact in one individual, this means that two visions of the world come into contact

\footnotetext{
Corresponding author: dfl@kti.ru
} 
and conflict. The transition from one language to another can cause deep shocks in thinking. Therefore, this study of the ongoing social and linguistic processes in the chosen linguistic area will be conducted through the prism of the "linguistic personality in the extreme conditions of existence" concept, i.e. in conflict [4].

Complex specific character of linguistic processes in the Central and Lower Volga regions in the past, an even more complicated specific linguistic, ethnic and cultural situation at present have determined the relevance of the research theme. Point island, mostly Western Central German mixed sub dialects of Kamyshin district in Volgograd region were the object of the study. The German settlements were founded on this territory in 1767 , during the period of the German colonies intensive development in the Volga region and shared the fate of all Russian Germans during the repressions in 1941. The choice of the object of study is determined by the uniqueness of the ongoing historical and linguistic processes.

\section{Materials and methods}

Oral and written texts recorded in oral and written speech of the German nationality people in settlements of Kamyshin district were taken as the basic materials of the study. In the process of collecting and processing speech material, a number of research trips were undertaken during 1995-2015.

The purpose and objectives of the sociolinguistic research have determined the method of collection and further analysis of the material. Since the island (colonial) dialectology explores linguistic objects, it uses mainly the same methods as other linguistic disciplines. At the same time, colonial dialectology also uses specific methods and techniques. It is the focus on territorial dialects and sub dialects, separated from the territories of the earliest diffusion of one or another national language that caused use of the above methods.

Like any other linguistic research, the language island dialects study includes three main stages: 1) collection and processing of the material; 2) presentation of the collected and processed data; 3) their interpretation. The distinctive character of the language island dialects study affects even the preparatory stage in defining the direct object of the study, since dialectologists collect and explore only those linguistic facts that reveal diatopic differences or similarities with the general national trend of language development.

Before starting the study, we considered it necessary to ascertain the opportunity to examine the chosen language island in the dialectological, general linguistic and sociolinguistic aspects. It was achieved by random sampling and use of our predecessors' works. However, we faced German sociolinguists' criticism of the quantitative deficit of research subjects (10 102 ethnic Germans of different ages lived in Volgograd region in 2010) [1]. An argument for further research was the fact that the German settlements of Kamyshin District were rather old and large enough settlements. They have existed so far, they are dialectally homogeneous in their core composition. The above argument ensured a sufficient choice of respondents and significance of the research results for documenting and archiving endangered island dialects.

Provisions reflected in questionnaires and research programs of the Volga German dialects were taken into account when selecting informants [5,6]: 1) belonging of informants to a certain age, sex and social groups; 2) the origin and family composition; 3) continuity of settlement traditions or mobility of an informant (his family) within a region (country); 4) religious affiliation; 5) education; 6) ethnic composition of the region of residence; 7) the informant's "linguistic loyalty", defined as close relationship of national identity with the informant's language competence [7]; 8) the communication situation nature; 9) the material functional and stylistic markedness, which made it possible to specify the circle of people who meet the objectives of the study most fully, to identify the peculiarities of the island dialects current state.

Bilinguals of various age and sex, educational qualifications and occupations were involved as informants. A total of 990 minutes of speech recordings of 60 informants aged from 60 to 90 were analyzed. Method of free conversations linked by common themes without direct and prompting questions was used to obtain the material. Questions of a family and family relations, agriculture, stories about holidays, rituals and customs, about childhood in the native village and memories of the period of deportation were the topics of conversations. The use of Venker's sentences was intended to have a control character in this study.

At the second stage of the language island study, the collected and processed material was presented as a system characteristic of phonetic, grammatical and lexical phenomena.

The research scientific novelty is related to the fact that there are still few works devoted to identifying the peculiarities of island dialects development in the conditions of German-Russian bilingualism, based on materials of the Volga German language range.

\section{Results and discussion}

In the domestic linguistic literature there is no direct equivalent of the German dialectological term "Sprachinsel", which denotes "some marginal language area, separated from the main area of its diffusion by political borders, located within the territory of the foreign language majority" [8]. Austrian Germanist P. Wiesinger defines this term as “... isolated relatively large, closed linguistic settlement-type communities in foreign-language, relatively large areas" [9]. The closest translation of this term is "language island". Besides there is the Russian term "island subdialect" close to the meaning given above. It denotes a subdialect surrounded by another language. Unlike this Russian term the concept of "language island" is more inclusive. It provides for coexistence and contacts of several language formations within a limited space. On the one hand, coexistence of special isolated dialectal groups is 
emphasized, on the other hand, their speakers' complex relationships with the surrounding majority of other languages speakers are highlighted. The linguistic characteristics of such groups can only be analyzed in comparison with the national language or other languages data, that is, with the linguistic environment of the studied language island.

The language island is understood not only from the linguistic point of view, but also as "the general term for all life manifestations of a community living within a language island" (toponymy, onomastics, ethnography, etc. are also meant) [10]. There is an interpretation of the language island as "... separated from the national language community by other languages and cultures of marginals, leading (at the language and often cultural level) interesting independent life", revealing very often only weak links with both their historical homeland and with the state surrounding them [11].

Any language island has a feature of "overlap" (Überdachung) with the language of the surrounding population or "language majority" due to the prevailing practical role and social prestige in the society. It will over time lead to increased influence of the foreign environment and foreign language on the above language island. High social status of the surrounding language "majority" inevitably makes the island dialect speakers master the surrounding population language, whereas ties with their ethnic literary language often begin to weaken. Thus, the path taken by the language development is from ethnic and national diglossia (dialect / literary language) to different variants of bilingualism: 1) dialect / literary language + foreign literary language, or 2) dialect + foreign literary language.

According to the opinion of some scholars, the German "Sprachinselforschung" (language island study) is understood as a discipline, the subject of which "is the study and presentation of the German language islands as closed, strongly dissociated living units" [12]. The concept of "Sprachinsel" (language island) adopted in foreign linguistics denotes some marginal area of language diffusion, separated from the main area of its existence by political borders, located within the territory of the foreign language majority. This concept successfully reveals the peculiarities of intra- and extra linguistic processes in the dialect language bilingualism context.

Linguistic study of the German language islands in Russia occupies an important place in the German dialectology and social linguistics [13]. Germanists mainly consider and describe language islands of the Siberian region [14-19]. We find it appropriate to consider all linguistic and cultural processes in the Lower Volga language islands in the context of "conflict" with the surrounding majority, namely, the difference in structure and amount of code (language) of the communicative act participants.

The analysis of the German language islands of Kamyshin District in Volgograd Region revealed a number of important patterns in the existence and development of such island subdialects.
Languages and dialects coexisting in confined spaces experience complex processes of interaction and development.

Development of dialectal systems under the direct and indirect influence of the national language and other dialects results in changes in the language island. Besides island dialects speakers are strongly influenced by the language and culture of the foreign majority in a complex exoglossic unbalanced language situation.

Thus, the studied type of language contacting can be designated to contacts of one language (German) and everyday colloquial and literary form of another language (Russian). Structural and genetic relations are defined as contacts of distant close cognates that have only a common Indo-European basis. The languages studied have different official communicative status, the native speakers currently reside in a settlement of heterogeneous national structure (intraregional contacting). The two languages interact directly in natural conditions; these permanent language contacts result in mostly one-sided influence of the Russian language on various levels of the German subdialects.

From the linguistic perspective, as mentioned above, a language island develops from ethnic and national diglossia (dialect / literary language) to mastery of two language systems, to different forms and types of bilingualism.

German and Russian bilingualism in the studied area is characterized as unilateral (Germans mastered Russian, but Russians do not speak German), mass (almost all Germans speak Russian), natural (constant contacts with Russian-speaking population result in natural way of mastering this language by Germans), subordinate (unequal language skills in two language systems) bilingualism.

Five consecutive transitional stages from German to Russian can be observed in language islands. This allows distinguishing several separate groups characterized by: 1) active German monolingualism; 2) active and passive German-Russian bilingualism; 3) active German-Russian bilingualism; 4) passive and active German-Russian bilingualism; 5) active Russian monolingualism. The analysis of selected informants groups clearly shows function and development features of the German language dialect systems.

Change of different systems of subdialects as part of a language island is a complex process result. On the one hand, foreign language elements (Russian) are assimilated; on the other hand, elements of the national German language system are assimilated and developed under the influence of the literary German language and neighbouring dialects.

Manifestation of new processes can take different forms at the levels of subdialects system. Lexical system has the highest permeability. The Russian language influence on the German colonists' vocabulary is often expressed in direct borrowings of Russian words, such as stolar "Tischler" (carpenter), pirog "Kuchen" (pie), samovar, etc.

According to G. Dinges [20], no more than 800 borrowings entered the German colonists' language until 1876. This can be explained to a greater degree by the 
status of arriving people. They were not immigrants, usually adapting to a new environment, but colonists whose culture, religion and language differed from the local ones. In addition, almost all colonists followed a rural lifestyle, which is also one of the key factors to preserve the dialect purity in a foreign language environment.

All borrowings from Russian into the Volga Germans subdialects can be divided into the following lexicalsemantic groups and subgroups:

I. The first group includes words related to the field of national and public life: 1) administration and administrative staff: starost (starosta, mayor), storo $\int$ (storozh) "watchman", predsedatel "chairman", raitsentr "regional center"; 2) legislation: ukaz "decree", militsioner "policeman"; 3) financial relations: poflin (poshlina) "duty", dengie (den'gi) "money", sberkase (sberkassa) "savings bank"; 4) public law relations: tjurme (tiur'ma) "prison"; sud "court"; 5) local selfgovernance: duma "duma", deputat "deputy", selsovet "village council"; 6) the land community organization: kolektiv (kollektiv) "collective", kolhoz "collective farm", brigade (brigada) "brigade", otdelenie "branch"; 7) measures and money: desjatine "tithing", t fetvert (chetvert) "quarter", ku: 1 (kul') "sack", pud "pood", rubel "rouble", tysjatfa (tysiacha) "one thousand", kope: (kopeiyka) "penny"; 8) national religion: pope "priest", tserkva (tserkov) "church" (meaning Orthodox).

II. Tribes and peoples: girgizen (kirgizy) "Kirghiz", tartaren (tatary) "Tartars", morduinen (mordva) "Mordva", kalmuken (kalmyki) "Kalmyks", kazaken (kazaki) "Cossacks", koholen (khohly) "Ukrainians".

III. The next, a large word group relates to the area of trade and economic relations (industry and agriculture). In the field of trade relations, industrial and agricultural production, the following borrowings were found: 1) trade and industry: t $\int$ ot (schyoty) "counting frame", pristan "pier", magazin "shop", bovar (povar) "cook", utfilife (uchilische) "school"; 2) agriculture: arbus (arbuz) "watermelon", baxtfa (bakhcha) "melon field", tabune "herd".

IV. Nature. New environment conditions contribute to emergence of new borrowings in this area, for example: stepe "steppe", zaton "backwater", suslik "gopher", etc.

V. Discrepancy between the number of borrowed words and the number of borrowed or adopted facts is clearly found in that group of old borrowings recorded by G. Dinges, which belongs to the field of private life, to everyday life, to the field of material culture, family life and to the field of morals and customs: baba "female" is a derogatory name for a woman of any nationality, including Germans; maslitsa (maslenitsa) "Pancake Week", kalat (khalat) "robe", fi (schi) "cabbage soup", bline (bliny) "pancakes", kvast (kvas) "quass", vodka "schnaps", brafke (brazhka) "brew".

Many of the listed borrowed words are used in the language regularly, while others, on the contrary, pass in the category of archaisms and historicisms.

Observations of the ethnic Germans' names are also interesting. As a rule, the older generation of the language island population has German names:
Elisabeth, Theresa, Frida, Christiane, Jakob, Johann, Fridrich, etc. But in everyday communication traditional German home names and nicknames are used together with the Russian ones: Elisabeth - li:she - Lilya or Lisa; Christiane - kri:she - Kristya or Khristia; Jakob - Yasha or Yashka; Georg - Jarik - Jora or Zhorik; Fridrich Fedor or Fedya. As can be seen from the above material, Russian diminutive names and nicknames appear when there are correspondences between the German and Russian proper names. When the younger generation address old people "everyday forms of politeness" are also used in the language island: feter van'a "Uncle Vanya (Johann)", babufka fri:da "Grandma Frida".

The use of the Russian proper names can be explained by the desire to integrate with the Russian population. In this case, various factors, including fashion (see above) have effect.

The Russian nicknames are usually given to domestic animals.

Economic phenomena cause vocabulary borrowings (primarily in the field of economics and everyday life) of the selected lexical-semantic groups.

Thus, we can conclude that the number of borrowings in the language island under study increases, and outdated concepts are transferred to the passive vocabulary of dialect speakers (Dorfsowjet (sel'skiy sovet) "village council").

Words can be borrowed from one language to another in different ways. Firstly, it can be words associated with objects and their names. Secondly, words can be borrowed as new designations for the concepts that are already known. Linguistic status of such new word forms should be examined more closely, in particular from the point of view of code switching concept (code switching). This question remains understudied, but it is of particular interest. The colonists' general German-Russian bilingualism raises a number of new questions and problems. As the speaker masters various language codes, prerequisites for the transition from one language to another directly in the process of communication appear [21-23]. In this case, we can talk about the inclusion of a separate word or phrase, that is, a mixture of code is observed. In other cases, the speaker switches from one language to another, that is, The most stable and comprehensive factor in the language island verbal system development is the desire for rationality in the use of language means. In this case, language units alignment by analogy and forms differentiation by value can be observed. Compare iç hun, mir hun «ich hatte, wir hatten». Analytic word forms of verbs use make up half of the tense forms in informants' speech. There exists analytic and synthetic forms balance: on the one hand, the preterite displaces the perfect tense (di ela hot das ferkes(e); iç hat net gvust), on the other hand, the present tense function expands (in neçst jo:r tut zi di Ju:l endix; iç ka:f damols kanza sumka fol) the code switching (mixing). But if speech codes nature, transition from the native language to a foreign language or vice versa, frequency of such transitions is considered, then many borrowed words and expressions in bilingual speech can be represented as special cases. The criterion of these words "recurrence of 
nonce use" is not always applicable for classification, since in some conversational topics the code change takes place more regularly. The criteria for phonetic, phonological and grammatical integration of borrowed words in the target language sometimes do not give a definite answer to the question of interest. So, borrowing from the Russian language used in the target language without interference is considered a "quotation" [24] (balvan!, hospodibomile!, durak). But at the same time, there are transitional cases that indicate both the code switching features and lexical borrowing. The so-called hybrid words can be an example: makkhuxe "poppy seed cake". The number and nature of foreign words depends on the theme of the text. The recorded texts of our respondents about their childhood and the era of repression differ significantly in terms of language. There are early assimilated foreign language borrowings in the texts of the first type, for example, the names of dishes (see above). Non-adapted words use is extremely rare, for example, gast'intsy (gostinitsy) "hotels". Switching or mixing codes is often recorded in stories

it is found. And the general structure study before and after a change can give an answer to the question whether this innovation sourse is within the above language system or it is another language influence.

There are fewer verbal than noun borrowings in the speech of the studied language island representatives. Nouns function more widely in the dialects, though they are not mastered fully in grammatical expression. The verb and its semantics play a dominant role in the sentence structure building. Therefore, the verb system replenishment with foreign borrowed elements is by morphological restructuring of the entire verb system and loss of units morphological expression in the source language. Foreign verbs obligatory continue using the paradigm of the German language verbal system conjugation (iᄃ gelai, du gelaist, er gelait, mir gelaie, ihr gelaiet, zi: gelaie, er hat gegelait). Nonadapted morphological forms are isolated examples (davai, ofibat'sa (davay, oshibat'sy) "let's", “mistaken”).

Morphological level of subdialects systems has a complicated indirect link with the language communicative function. Their units can only be in the composition of other units (words), therefore, they serve as a small obstacle to mutual understanding, since their disparity forms only partial differences in the used communicative units. Compare the competing plural forms of the noun me:d $\zeta$ «das Mädchen» (devochka

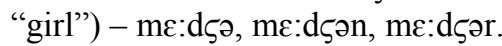

The most stable and comprehensive factor in the language island verbal system development is the desire for rationality in the use of language means. In this case, language units alignment by analogy and forms differentiation by value can be observed. Compare iç hun, mirhun «ich hatte, wir hatten». Analytic word forms of verbs use $m$ ake up half of the tense forms in informants' speech. There exists analytic and synthetic forms balance: on the one hand, the preterite displaces the perfect tense (di ela hot das ferkes(ə); iç hat net gvust), on the other hand, the present tense function about a special settlement life. On the one hand, it is caused by the topic itself, the need to describe the Russian environment and the details of the Russian life, on the other hand, it is the need to convey new realities. This problem has been largely unexplored topic so far. The role of contacting languages structure requires more detailed philological, sociolinguistic and psycholinguistic studies.

Any language is not a random collection of words and sounds, but a well-organized and internally coherent whole. When two languages contact, this means that people will have to use two different language structures for communication purposes. In this connection the main linguistic problem is to define the extent of inalterability and mutual interaction of two contacting language structures. Our observations have shown that complete independence of both linguistic structures in situations of bilingualism is rare. A language change can be fully explained only in the light of its connection with the general structure of the language in which

expands (in neçst jo:r tut zi di Ju:l endix; iç ka:f damols kanza sumka fol).

As for the noun morphological markers, destruction of case inflections system is characteristic of the language island subdialects of the village of Gebel. There is a tendency to case endings unification (nominative, accusative and dative cases mixture, for example, air khind, mit air khind, fir air khind transition to a single form, conveying subject and object relations). The genitive case of names with the basic meaning of belonging becomes obsolescent in subdialects (s' dax fon haus, d' klaid air muder). Archaization of many subdialect phonetic features is inherent even with people who practically switched to using normalized German speech or Russian. The invariability of some phonetic features is explained by their systemic nature. Their basis is formed by differences related to existence of various phonological oppositions and positional dependence types that have only a long, gradual changeabale nature (beser - bezer, voxe - voye, khind, phunt).

Morphemics of the plural of nouns indicates only minor formal differences and stability of nominal forms. As a rule, only one differential marker of the plural form is preserved in subdialects. It is either umlaut or finite inflection, the both ones together are rare cases. Compare daf - dafer (das Dorf - die Dörfer), ku: - ki: (die Kuh - die Kühe). This eliminates redundancy in grammatical expression.

Old and new elements balance in the dialectal systems differ in surveyed groups of dialects speakers of the older generation, for example, hun (the first group (I), aged from 90 to 75) - habe (the second group (II) from 74 to 68 ) - hab (the third group (III) - from 66 to 60); d' klaid mair muder (I) - d' klaid von mai muder (II) - klaid mai muder or mamin klaid (III).

The dialectal systems are dependent on the general trends of the national language system development. Their steady preservation of the verb and noun main features system follows herefrom. Thus, according to the 
outcomes of the study the following phonetic phenomena and grammatical forms have more invariability:

1) transition of the voiceless obstruent spirant after the main stressed syllable to the corresponding voiced one, if it is preceded by a vowel or sonant and is followed by a vowel (laut - lauder, beser - bezer);

2) pronounciation of the sounds $-\mathrm{k}$ - and $-\mathrm{p}$ - in the first syllable before a vowel with aspiration (khint, khome, phunt);

3) the plural forms of nouns for all genders are largely preserved (the plural from masculine nouns is formed with the suffix -e without umlaut or with umlaut (strong declension) - tif-tife, dax-dex, zon - zene, vare ve: $\gamma \mathrm{e}$; the suffix -(e)r - mund - minder, vald - valdr; the suffix -e(n) (weak declension) - buv - buve, name namen; from neuter nouns suffix - (e)r - daf - dafer, klad - klader; suffix -e (as a rule a reduced one) - jo:r jo:r(e), tor - tor; from feminine nouns suffix -e either with or without umlaut $-\int \mathrm{u}: 1-\int \mathrm{u}: \mathrm{le}$, tsaidun - tsaidune);

4) a number of verbal tenses, voice and mood forms (present active, perfect active, present passive and stative, perfect passive and stative, pluperfect passive and stative, preterit stative, imperative of the second

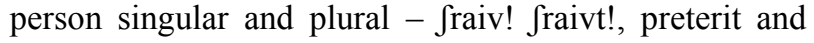

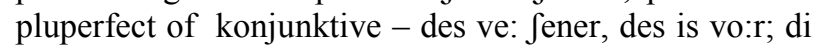
het bezantvorte ken);

5) forms of the verb person and number of the present and past tense (for the present indicative active in the second person singular, the ending is - st, for the third person singular and for the second person plural the ending is $-t$, in the first and third person plural, the ending is $-(\mathrm{e}) \mathrm{n}$, it is often reduced; zero ending is characteristic for the preterit indicative active in the first and third person singular, the ending - st for the second person singular and the ending $-t$ for the second person plural, the ending -e for the first and third person plural).

Importance and singularity should be emphasized in nouns and verbs expression. Nouns are characterized by:

a) gradual lessening the formal differences between nominative and accusative, accusative and dative (den halbbruoder - der halbbruoder «main frau habt $\mathrm{dr}$ halbbruoder», in dr Ju:1 - in d'Ju:1 «g $\int i k t$ in d'Ju:1 - lernt in d' $\left.\int u: 1 »\right)$;

б) lack of direct dependence on use of one or another type of external or internal inflection to designate the plural and the gender of the noun, except for one pattern: the suffix -(e)r does not express the plural feminine (that is acceptable: bed - bede or beder, man - mener or mane, but naxt - neçte, tsaidun - tsaidune). Verbs are characterized by:

a) alignment of forms by analogy and differentiation of forms by value;

b) balance of analytical and synthetic forms;

c) full adaptation of borrowed Russian verbs to the subdialect system.

Special mention should be made of verbal forms good preservation, which is quite typical for subdialects experiencing foreign language or dialect influence.

The most significant changes in the studied island subdialects appear:
1) in the gradual displacement of the residual vowels nasalization in front of nasal sounds by the regional

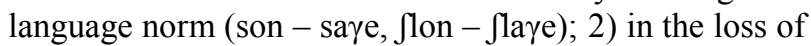
the noun genitive forms (das Haus meines Kindes - s' haus maim khind or maim khind sin haus, etc.);

3 ) in the case system unification (a gradual transition to a single form conveying subject and object relations);

4) the increase in the proportion of the second participle weak forms in the total number of participle use;

5 ) in the loss of the present forms of konjunctive;

6) in the tendency to the loss of the imperative of the first person plural;

7 ) in the absence of the future tense special forms (futurum I is used limitedly only to designate an action with explicit seme of the future tense);

8 ) in the loss of preterit indicative forms (in the language island the preterit remained only for full verbs kommen and gehen, from the verbs haben and sein, and from the group of preterit and present verbs wollen, sollen, müssen, können, dürfen, wiessen) and limited use of pluperfect;

9) in the expression of the perfect (expansion of the scope of the auxiliary verb use - haben: hat $\mathrm{kftorve}$, hat gfli:xt;

10 ) in the predominant use of the stative, rather than passive.

A great communicative role of a number of verbal categories (person, number, tense) has received confirmation. In some cases, the deviations coincide with the common German language tradition (for example, reduction of finite $-\mathrm{e}$ and - (e) $\mathrm{n}$ in personal endings, etc.).

\section{Conclusion}

The study outcomes prove that the current island subdialects of the Lower Volga region can be defined as variants of the German language dialect systems (Western Central German), but as special ones having no analogues in their historical homeland, which is caused by specific historical (social and linguistic) conditions that determined the characteristic patterns of building subdialects.

Contrary to linguistic forecasts, the German subdialects continue functioning and even developing in the designated linguistic area, as it can be seen from the results presented in the study.

The ethnic identity of the Volga Germans (the cultural one comes from it) is oriented, as noted above, on such objective signs as language, religion, territory, material culture. The problems of national origin at turning points of a person's life can lead to the increase in ethnic identification simply because they are realized more than in a normal state. Cultural and language elements that were previously important in the prevailing historical events, as a result of strong assimilation processes, were hardly required (language, customs) or prohibited (religion), limited by law (territory of settlement) - become a means of persuasion and cohesion. Minority representatives whose identity is 
threatened with loss, preserve and emphasize their ethnic cultural and language origin more often than members of the majoritarian society.

\section{References}

1. Information materials on the final results of the 2010 all-Russian Population Census (2010), retrieved from:

http://www.gks.ru/free_doc/new_site/perepis2010/pe repis_itogi1612.htm

2. N.A. Frolova, Particular characteristics of the island subdialects development in the conditions of German and Russian bilingualism: on the material of the subdialects of the village of Gebel, Kamyshin District, Volgograd Region: extended abstract of candidate of philological sciences thesis: 10.02.19. (Saratov, 1999)

3. N. Berend, H. Jedig, Deutsche Mundarteninder Sowjetunion. Geschichteder Forschung und Bibliographie (Marburg, 1991)

4. N.A. Frolova, To the issue of preserving national and cultural identity in the context of conflict, Innovative technologies in education and production. 3, 224228, (2008)

5. G. Dinges. Zur Erforschung der wolgadeutschen Mundarten. Ergebnisse und Aufgaben, Teuthonista 1 (4), 299-313 (1925)

6. A. Dulson, Zur Fibelfrage Wolgadeutschen, Schulblatt, 481-483 (1927)

7. P. Rosenberg, Orientierungen für eine moderne Sprachinselforschung (Frankfurt am Main, 123-164 1994)

8. A.I. Domashnev, German settlements on the Neva (from the history of "island" dialectology development), Voprosy` yazy`koznaniya, 1, 24-32 (1996)

9. P. Wiesinger, Deutsche Sprachinsel. Lexikon der Germanistischen Linguistik (Tubingen, 1980)

10. C.J. Hutterer, Dialektologie. Ein Handbuchzur deutschen und allgemeinen Dialektforschung (Berlin; New York, 1982)

11. H. Protze, Die Bedeutung von Mundart, Umgangssprache und Hochsprache in deutschen Sprachinsel unter Berücksichtigung sprachlichen Interferenz, Wissenschaftliche Zeitschrift der Universität Rostok. Gesellschafts-und sprachwissenschaftliche Reihe, 6-7 (1969).

12. W. Kuhn, Deutsche Sprachinselforschung Geschichte, Aufgaben, Verfahren (Plauen, 1934)

13. P. Rosenberg, H. Weydt, Sprache und Identität. Neues zur Sprachentwicklung der Deutschen in der Sowjetunion. Sonderdruck aus Die Russlanddeutschen Gestern und heute (Markus Verlagsgesellschaft GmbH, Köln, 1992)
14. L.I. Moskalyuk, Features of development of lexicalsemantic system of German dialects in Altai, Sibirskii Filologicheskii Zhurnal 2, 196-207, (2018)

15. T. Moskvina, Changes in the lexical system and tendencies in German insular dialects of Russia (the Altai Krai, Russia), 24th Annual Conference on Language and Literature - Languages Connect. DeptGerman Language \& Literature, Brno, Czech Republic 22-24, (2016)

16. O.V. Baykova, A.V. Kazakov, O.N. Obukhova, Methods of determining and analyzing complete and incomplete intonation phrases in spontaneous speech (on the example of studying German insular dialects), Vestnik Tomskogo Gosudarstvennogo Universiteta, Filologiya (Phillogy) 54, 5-28 (2018)

17. O.V. Baykova, O.N. Obukhova, Y.V. Berezina, V.A. Banin, A.V. Kazakov, Ethnic identity and language variations of the Russian Germans in the Kirov region, International Journal of Applied Linguistics and English Literature 5(6), 152-157 (2016)

18. L.I. Moskalyuk, Reflection of features of colloquial speech in the shvank of Russian Germans, Vestnik Tomskogo Gosudarstvennogo Universiteta, Filologiya 40 (2), 45-56 (2016)

19. T.B. Smirnova, T.S. Kisser, Russian Germans diversity, Ural'skij Istoriceskij Vestnik 55(2), 4453 (2017)

20. N. Berend, P. Rudolf, Wolgadeutsches Sprachatlas. Aufgrund der von G. Dinges 1925-1929 gesammlten Materialen (A. Franke Verlag, Tübingen, Basel, 1997)

21. I.V. Aleshchanova, N.A. Frolova, M.R. Zheltukhina, Evolution of Motives in Professional Personality Formation: Foreign Language Learning Context. Proceedings of the International Conference on the Theory and Practice of Personality Formation in Modern Society (Ictppfms 2018), 198, 35-40 (2018)

22. E. V. Bobyreva, O. A. Dmitrieva, M. R. Zheltukhina, and M. V. Busygina, Principle "Understanding" from Perspective of Linguistic Investigations, Proceedings of the 7th International Scientific and Practical Conference Current Issues of Linguistics and Didactics: The Interdisciplinary Approach in Humanities (CILDIAH 2017). Advances in Social Science, Education and Humanities Research (ASSEHR), 97, 52-56 (2017)

23. T.Yu. Tameryan, M.R. Zheltukhina, I.G. Sidorova, E.V. Shishkina, Stereotype Component In The Structure Of Ethnocultural Archetype (On InternetBlogs), The European Proceedings of Social \& Behavioural Sciences, 200, 1716-1722 (2019) doi: https://dx.doi.org/10.15405/epsbs.2019.03.02.200

24. L. Naiditsch, Sprachinselforschung. Eine Gedenkschrift fur Hugo Jedig (Frankfurt am Main 31-45, 1994) 